\title{
Strategi Kualitas Pelayanan untuk Meningkatkan Reputasi Perusahaan
}

(Studi Empiris Pelanggan Go-Jek di Jakarta, Depok, Bogor dan Bekasi)

\author{
Shifa Nurbaiti' ${ }^{1}$, Zulkifli ${ }^{2}$, Derriawan ${ }^{3}$ \\ 1,2,3 Universitas Pancasila \\ Email: shfnurbaiti@gmail.com ${ }^{1}$
}

\section{ARTICLE INFO}

Article History:

Received: April 14th 2021

Accepted: April 26 2021

Published: May $6^{\text {th }} 2021$

Keywords:

Kualitas Pelayanan,

Reputasi Perusahaan, Strategi

\begin{abstract}
Tujuan penelitian ini adalah untuk mengetahui Strategi Kualitas Pelayanan Untuk Meningkatkan Reputasi Perusahaan Go-Jek. Penelitian ini menggunakan metode penelitian kuantitatif dan kualitatif (mix-methods). Teknik pengambilan sampel menggunakan purposive sampling. Pengumpulan data menggunakan kuesioner. Teknik analisis data menggunakan analisis Structural Equation Modeling (SEM) yang diolah dengan Smart PLS 3.0 untuk analisis kuantitatif, sedangkan untuk analisis kualitatif menggunakan SWOT, CPM, dan QSPM. Hasil penelitian kuantitatif membuktikan bahwa kualitas pelayanan, kepercayaan online dan kinerja driver masing-masing berpengaruh terhadap kepuasan pelanggan maupun terhadap reputasi perusahaan. Sedangkan kepuasan pelanggan tidak berpengaruh terhadap reputasi perusahaan. Adapun hasil penelitian analisis strategi melalui tahapan strategi input stage dengan CPM, matching stage dengan TOWS dan decision stage dengan QSPM maka strategi yang digunakan dari hasil QSPM adalah strategi alternatif pengembangan produk.
\end{abstract}

\section{Pendahuluan}

Era informasi ini, hampir seluruh eleman masyarakat yang terkoneksi dengan internet akan selalu mengakses layanan mesin pencari, layanan ini melibatkan serangkaian aktivitas yang memungkinkan digunakan pada halaman web untuk mendapatkan peringkat halaman pertama atau teratas dari URL tertentu dan memberikan hasil yang relevan (Husain, Sani, Ardhiansyah, \& Wiliani, 2020). Aplikasi tersebut saat ini bahkan sangat mudah diakses pada smartphone yang dimiliki masyarakat. Arus informasi dan pesatnya akan pengetahuan global berbasis jaringan internet ini membuka gaya hidup dan fenomena di kalangan masyarakat dengan akses dan layanan terbuka hingga pelosok tanah air (Wahyuni \& Setyawati, 2020), seperti halnya layanan Go-Jek yang memberikan kebutuhan utama bagi penggunanya sebagai transportasi alternatif yang cukup mudah, cepat dan ekonomis. 
Fenomena Ojek Online di Indonesia memberikan solusi akan kekhawatiran masyarakat tentang kemacetan yang sering terjadi di kota-kota besar dan tentang jaminan keamanan penumpang yang menggunakan armada transportasi umum atau konvensional (Kurnianti, 2017). Ojek Online banyak diminati oleh masyarakat diantaranya memiliki kelebihan yaitu aplikasi berbasis yang data, dimana masyarakat dapat mengetahui identitas pengemudi kendaraan bermotor. Dengan kelebihan ini, masyarakat bisa mendapatkan informasi siapakah yang akan menjadi pengemudi layanan transportasi yang telah di pesan, lengkap dengan data diri pengemudi atau driver yang bersangkutan (Windasari \& Zakiyah, 2019). Ojek Online sangat mengedepankan faktor keamanan pengguna biasanya di dalam aplikasi sudah tersedia informasi lengkap tentang pengendara seperti nama, kontak, dan foto pengendara (Anindhita, Arisanty, \& Rahmawati, 2016). Layanan Ojek online hanya bisa diperoleh dengan pemesanan via aplikasi-aplikasi transportasi online seperti Go-jek, Grab dan lain sebagainya, sehingga pelanggan dapat memastikan keamanan dan akuntabilitasnya.

Belakangan ini sering kita jumpai berita di media massa dan sosial mengenai Go-Jek. Mulai dari pelayanannya, drivernya, promonya, pesaingnya, konflik dengan ojek pangkalan, bahkan yang terbaru ini diberitakan ORGANDA menilai Gubernur DKI Jakarta keterlaluan karena membela Go-Jek. Padahal Go-Jek bukanlah transportasi melainkan layanan perantara antara Tukang Ojek dan pelanggannya yang merupakan sebuah kemajuan dan manfaat dari teknologi. Sebelumnya pun Organda tidak pernah protes dengan adanya ojek. Lagi pula, apakah transportasi umum di Jakarta seperti Bus, Angkot dan sebagainya sudah dikayakan layak, bahkan banyak sekali masyarakat yang merasa "Tidak Nyaman" saat menggunakan Transportasi Umum. Di samping itu, Go-Jek dan Grab, keduanya telah menguasai hampir seluruh pasar transportasi online di Indonesia. Namun, belakangan ini posisi tersebut terganggu dengan kehadiran beberapa transportasi online baru yang meramaikan pasar transportasi online Indonesia, yaitu: Anterin, Maxim, Cyberjek, Bonceng, BeU Jek. Keseluruhan transportasi online tersebut menggunakan infrastruktur komputasi awan yang mengkombinasikan mekanisme portabilitas antara data dengan komputasi awan dengan aplikasi atau dikenal dengan istiliah platform cloud hybrid (Quintania, Faturachman, Husain, Pasupati, \& Taufik, 2021).

Persaingan bisnis yang semakin kompetitif, kebutuhan akan efisiensi dan efektivitas dalam pengelolaan itu sendiri menuntut setiap organisasi untuk siap dan mengadopsi penggunaan teknologi tersebut (Sani, Abdul Rahman, Subiyakto, \& Wiliani, 2019). Kehadiran layanan aplikasi tersebut membuat pasar layanan on-demand semakin menarik. Model bisnis platform sedang menjadi perhatian saat ini dengan cepat menjadi tools yang membentuk suatu ekosistem dari dua sisi yaitu pasokan dan permintaan itu sendiri (Sugiyarto, Dewi, \& Junaedi, 2020). Strategi Go-Jek dalam menghadapi persaingan tersebut, agar Go-Jek agar tetapmenjadipilihanhatimasyarakat Indonesia dalam dunia Ojek digital adalah dengan berusaha memahami kebutuhan pasar dan karakter konsumen atau yang biasa disebut local insight penting untuk memimpin pasar. Hal tersebut tampaknya dimengerti betul oleh Founder dan CEO Go-Jek Nadiem Makarim (Ermaningtiastuti, 2019). Setelah memahami semuanya, poin berikutnya yang harus dilakukan adalah menerjemahkannya ke dalam inovasi teknologi. Keseluruhan proses tersebut diyakini menjadi strategi apik untuk memimpin pasar. Pemerintah hendaknya juga mengarahkan Ojek Pangkalan untuk bergabung dengan Go-Jek agar Ojek pangkalan lebih terorganisir. Sekadar diketahui, 
tarif Go-Jek lebih pasti karena ditentukan lewat aplikasi sehingga tidak perlu tawarmenawar.

Berdasarkan riset Google, Temasek dan Bain \& Company yang bertajuk e-Conomy SEA tahun 2019, pangsa pasar (gross merchandise value/ GMV) ride hailing (jasa layanan antar makanan dan transportasi online) di kawasan ASEAN hanya US\$ 3 miliar. Namun, pada tahun 2019 meningkat menjadi US\$ 12,7 miliar dan diproyeksikan menjadi US\$ 40 miliar pada tahun 2025 (Eka, 2018).

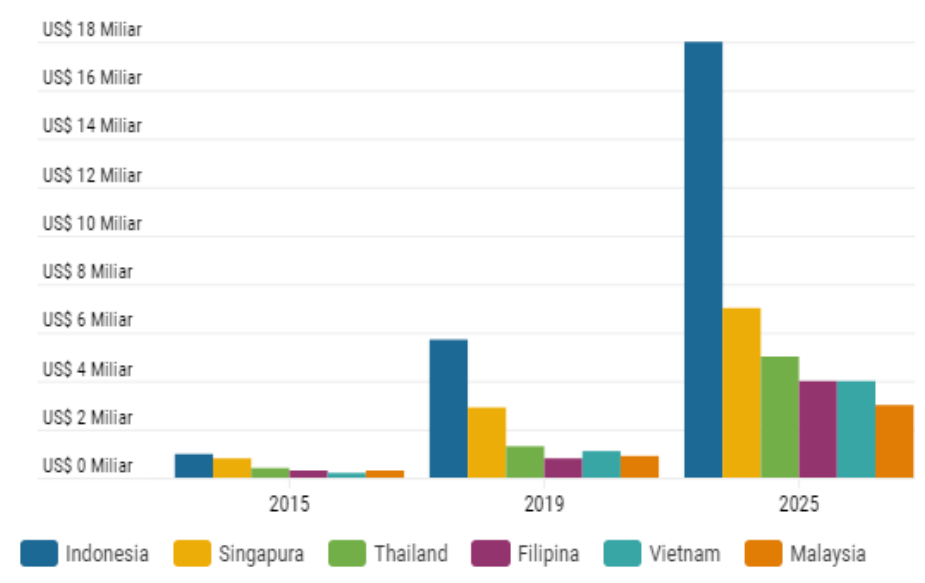

Gambar 1. Pangsa Pasar Transportasi Online di Kawasan Asia Sumber: Databoks, 2019

Gambar 1 menyajikan informasi jumlah pengguna aktif ride hailing di kawasan Asia Tenggara mencapai 40 juta, melonjak lima kali lipat dari tahun 2015. Adapun pangsa pasar layanan antar makanan baru mencapai US\$ 400 juta sedangkan layanan transportasi online sebesar US\$ 2,5 miliar pada tahun 2015. Namun, pada tahun 2019 GMV layanan antar makanan telah meningkat menjadi US\$ 5,2 miliar sementara transportasi online sebesar US\$ 7,5 miliar. Lalu, pada tahun 2025 layanan antar makanan online kawasan diproyeksikan menyamai GMV transportasi online, yaitu sebesar US\$ 20 miliar (Kusnandar, 2019). Saat ini terdapat dua layanan transportasi online terbesar di Indonesia, yaitu Go-Jek dan Grab.

Kualitas layanan yang semakin baik akan meningkatkan reputasi perusahaan. Akumulasi kualitas layanan yang baik secara terus-menerus akan membuat perusahaan dikenal sebagai perusahaan yang baik dalam hal layanan sehingga image perusahaan meningkat (Wulandari \& Rasipan, 2017). Image yang baik dimata konsumen menunjukkan bahwa perusahaan mendapatkan pandangan yang baik pula sehingga reputasinya meningkat. Di samping itu, pentingnya keahlian dan tingkat pendidikan karyawan serta keterampilan yang dimiliki bagi pelaku bisnis dan jiwa wirausaha dan faktor eksternal lainnya untuk dapat mengembangkan usaha (Sani, Pusparini, Rizal, Khristiana, Zailani, \& Husain, 2020). Kualitas layanan menjadi penting untuk membangun reputasi melalui rencana strategis dengan output yaitu loyalitas yang dibuktikan dengan hubungan yang signifikan berdasarkan kualitas pelayanan (Bakrie, Sujanto, \& Rugaiyah, 2019). Menurut Kotler dan Keller (2014:83), berbagai strategi dalam pemasaran produk dan jasa salah satunya dilakukan dengan memaksimalkan service quality kepada konsumen. Service quality sebagai salah satu strategi dalam pemasaran dapat diartikan sebagai suatu cara kerja perusahaan yang berusaha mengadakan perbaikan mutu secara terus-menerus terhadap proses, produk dan service yang dihasilkan perusahaan. 
Dua penyedia layanan on-demand Gojek dan Grab bersaing ketat supaya aplikasinya menjadi yang paling banyak digunakan. Caranya, dengan menyediakan beragam layanan sehari-hari diaplikasinya (SuperApp). Hanya keduanya menerapkan strategi yang berbeda untuk menjadi SuperApp. Kedua layanan aplikasi online di atas dan bahkan pesaing lainnya tentunya meningkatkan performa guna meningkatkan reputasi perusahaan.

Tabel 1. Persaingan Go-Jek vs Grab

\begin{tabular}{ccc}
\hline Keterangan & Go-Jek & Grab \\
\hline $\begin{array}{c}\text { Jumlah unduh aplikasi } \\
\text { Layanan pesan-antar } \\
\text { makanan }\end{array}$ & 142 juta & 144 juta \\
$\begin{array}{c}\text { Ride-hailing (motor mitra di } 370 \\
\text { mobil) }\end{array}$ & Di 178 kota di Indonesia \\
Layanan pembayaran & Go-Pay bermitra dengan & Grab menggandeng \\
& $\begin{array}{c}\text { Go institusi keuangan } \\
\text { dan ratusan ribu mitra }\end{array}$ & OVO di Indonesia \\
& di 370 kota & 9 juta (plus agen) di Asia \\
Cakupan & 204 kota di empat & 336 kota di delapan \\
& negara & negara \\
\hline
\end{tabular}

Sumber: katadata.co.id diolah peneliti, 2020

Data pada tabel 1 di atas, menggambarkan kondisi yang sangat rawan bagi Go-Jek apabila tidak segera meningkatkan kualitas layanannya karena pelanggan akan beralih kepada Grab jika kepercayaan pelanggan dalam kepuasannya menggunakan Go-Jek maupun reputasi perusahaan yang semakin tergerus oleh pesaing.

Online trust adalah kesediaan pelanggan untuk menerima kelemahan dalam transaksi online berdasarkan harapan positif mereka mengenai perilaku belanja online di masa yang akan datang. Terdapat hubungan yang positif antara kepercayaan online dengan persepsi reputasi perusahaan (Broutsou \& Fitsilis, 2012). Berbagai jenis jasa yang ditawarkan oleh aplikasi GOJEK tidak dapat dijalankan tanpa adanya peran dari para driver. Driver GO-JEK itu sendiri berasal dari berbagai latar belakang yang berbeda-beda, mulai dari pelajar, mahasiswa bahkan orang-orang yang telah memiliki pekerjaan yang kemudian menjadikan profesi driver Go-Jek sebagai pekerjaan sampingan. Adapun bentuk kerjasama antara driver dan Go-Jek adalah dalam bentuk kemitraan dimana berlaku sistem bagi hasil sebesar 80 persen untuk driver dan 20 persen untuk pihak GO-Jek. Semakin tinggi kinerja driver maka akan semakin tinggi pula pendapatan yang akan diperolehnya. Kinerja driver yaitu hasil dari sebuah pekerjaan yang dilakukan dengan penuh tanggungjawab. Secara etimologi, kinerja berasal dari kata prestasi kerja (performance). Istilah kinerja dari kata job performance atau actual performance (prestasi kerja atau prestasi sesungguhnya yang dicapai oleh seseorang) yaitu hasil kerja secara kualitas dan kuantitas yang dicapai oleh pegawai dalam melaksanakan tugas yang diberikan kepadanya (Mangkunegara, 2017, p. 67).

Yayasan Lembaga Konsumen Indonesia (YLKI) melakukan survei kepuasan masyarakat terhadap pelayanan transportasi online dengan melibatkan 4.668 responden. Ketika ditanyakan apakah konsumen pernah dikecewakan oleh pelayanannya, sebanyak 41 persen responden mengaku pernah dikecewakan, dan sebaliknya, 59 persen responden tidak pernah dikecewakan (Tim Peneliti YLKI, 2017). 
Tabel 2. Kekecewaan Konsumen pada Transportasi Online

\begin{tabular}{rlrr}
\hline No & Kekecewaan Konsumen & Jumlah & Persentase \\
\hline 1 & Pengemudi minta dibatalkan & 1041 & $22.30 \%$ \\
2 & Sulit mendapatkan pengemudi & 989 & $21.19 \%$ \\
3 & Pengemudi membatalkan secara sepihak & 757 & $16.22 \%$ \\
4 & Aplikasi map rusak/error & 612 & $13.11 \%$ \\
5 & Pengemudi tidak datang & 296 & $6.34 \%$ \\
6 & Kondisi kendaraan kurang baik & 282 & $6.04 \%$ \\
7 & Pengemudi ugal-ugalan & 221 & $4.73 \%$ \\
8 & Pengemudi merokok saat mengemudi & 35 & $0.75 \%$ \\
9 & Plat nomor tidak sesuai dengan kendaraan yang dibawa & 435 & $9.32 \%$ \\
\hline & & $\mathbf{4 6 6 8}$ & $\mathbf{1 0 0 . 0 0 \%}$ \\
\hline
\end{tabular}

Sumber: Data YLKI, diolah peneliti, 2020

Data pada tabel 2 di atas, menggambarkan bahwa tidak adanya standar pelayanan minimal yang diberikan oleh operator transportasi yang bersangkutan. Dampaknya potensi kerugian konsumen sangat besar yang hal ini apabila dibiarkan akan merusak reputasi perusahaan transportasi online khususnya Go-Jek sebagai penyedia aplikasi transportasi cukup dipercaya masyarakat.

Fakta ini adalah salah satu faktor yang menyebabkan pelanggan Go-Jek melakukan complain yaitu lamanya proses dalam mencari driver sehingga sering gagal dan harus diulang beberapa kali, driver Go-Jek yang kurang mengetahui mengenai rute tempat tujuaan, kedatangan driver yang lama sehingga merugikan pelanggan, dan aplikasi Go-Jek sering mengalami error. Dari keluhan tersebut nampak adanya penurunan kualitas layanan, berkurangnya kepercayaan pelanggan, driver tidak mampu mencapai kinerja yang bisa berdampak penurunan kepuasan pelanggan dan reputasi perusahaan. Secara logika kualitas jasa yang diberikan perusahaan juga sangat mempengaruhi reputasi dari perusahaan, jika kualitas jasa yang diberikan ke pelanggan baik maka reputasi perusahaan di mata pelanggan atau bahkan di mata para stakeholdernya juga baik pula. Pelanggan yang merasa puas dengan layanan dari Go-Jek secara langsung akan meningkatkan reputasi perusahaan sebagai penyelenggara transportasi online yang dapat diandalkan. Kepuasan pelanggan meningkat akan secara otomatis meningkatkan reputasi perusahaan yang yang dibuktikan dengan hubungan yang signifikan antara kepuasan pelanggan dan reputasi perusahaan (Husda, 2017).

Beberapa persoalan penting yang diidentifikasi dan perlu dikaji secara empiris antara lain kurangnya kesadaran perusahaan untuk mengevaluasi mitra Go-Jek serta penanganan komplain konsumen, persepsi yang ada di masyarakat tidak selalu dianggap baik, adanya persaingan bisnis transportasi dengan basis online dan konvensional yang menerapkan platform online-nya, kurangnya informasi yang diberikan oleh perusahaan mengenai pemanfaatan dan keamanan dari segi transaksi online Go-Jek, kurang pelatihan kepada mitra Go-Jek yang berdampak pada menurunnya kepuasan pelanggan serta kurang kreatifnya membuat strategi untuk meningkatkan kualitas pelayanan dan kepuasan secara menyeluruh. Oleh karena itu, penelitian ini bertujuan untuk menganalisis kualitas layanan, kepercayaan online, kinerja driver terhadap kepuasan pelanggan dalam meningkatkan 
reputasi perusahaan. Di samping itu, penelitian ini juga menganalisis strategi kualitas pelayanan Go-Jek.

\section{Kajian Teori dan Telaah Literatur}

\section{Kualitas Layanan}

Kualitas pelayanan menurut Zeithaml dan L. Berry (2009:94) adalah perbandingan antara pelayanan yang diharapkan konsumen dengan pelayanan yang diterimanya. Kualitas pelayanan merupakan keseluruhan ciri dan karakteristik dari suatu produk atau jasa dalam memenuhi kebutuhan dan selera konsumen (Lupiyoadi, 2013, p. 183). Kualitas pelayanan berfokus pada upaya pemenuhan kebutuhan dan keinginan konsumen serta ketepatan penyampaianya untuk mengimbangi harapan konsumen (Tjiptono, 2019, p. 248).

\section{Kepercayaan Online}

Kepercayaan adalah keyakinan salah satu pihak tentang tujuan dan perilaku pihak lain. Jadi "Kepercayaan konsumen diartikan sebagai harapan konsumen bahwa penyedia jasa dapat dipercaya atau diandalkan untuk memenuhi janjinya" (Widyastuti, Prasetyo, \& Gustari, 2017). Kepercayaan juga dapat didefinisikan sebagai suatu kesadaran dan perasaan yang dimiliki oleh pelanggan untuk mempercayai sebuah produk, dan digunakan penyedia jasa sebagai alat untuk menjalin hubungan jangka panjang dengan pelanggan (Diza, Moniharapon, \& Ogi, 2016). Kurangnya e-trust (kepercayaan online) kemungkinan akan menghalangi pembelian melalui internet (Broutsou \& Fitsilis, 2012). Oleh karenanya, kepercayaan online bertujuan untuk mengatasi masalah reputasi perusahaan, kepercayaan online, dan kepuasan dalam transaksi online.

\section{Kinerja Driver}

Kinerja merupakan telaah seseorang atas hasil kerja yang dicapai. Kinerja juga dapat didefinisikan sebagai suatu pengembangan yang menurut banyak ahli dengan perbedaan sudut pandang. Menurut Bangun (2012:231), kinerja merupakan hasil pekerjaan yang dicapai seseorang berdasarkan persyaratan pekerjaaan (job requirement). Menurut Mangkunegara (2017:67), pelaksanaan tugas seseorang dalam mencapai hasil kerja baik secara kuantitas maupun kualitas menjadi dasar tanggungjawab yang diberikan kepadanya (Sudaryana, 2020). Dimensi yang menjadi bagian dari kinerja adalah kuantitas kerja, kualitas kerja dan ketepatan waktu. Menurut Mondy (257-259), kinerja itu sendiri memiliki tujuan dalam penilaian perencanaan sumberdaya manusia, proses rekrutmen dan seleksi, perencanaan, pelatihan dan pengembangan karir, pemberian kompensasi serta hubungan antar karyawan internal dan penilaian potensi karyawan tersebut (Pujoraharjo, Zunaidah, \& Diah, 2015).

\section{Kepuasan Pelanggan}

Kepuasan pelanggan menurut Zeithaml dan L. Berry (2009:104) adalah penilaian pelanggan atas produk ataupun jasa dalam hal menilai apakah produk atau jasa tersebut telah memenuhi kebutuhan dan ekspektasi pelanggan. Kepuasan pelanggan dapat disimpulkan 
sebagai kunci untuk memberikan kepuasan pada pelanggan adalah berusaha mengetahui terlebih dahulu apa yang dibutuhkan dan diinginkan oleh pelanggan (Kotler, Philip T., Keller, Kevin Lane, 2014, p. 164). Jika performance gagal memenuhi ekspektasi, maka pelanggan menjadi tidak puas atau sebaliknya Jika sesuai dengan ekspektasi, maka pelanggan menjadi puas atau jika melebihi maka akan menjadi sangat puas atas penilaian pelanggan.

\section{Reputasi Perusahaan}

Kepuasan pelanggan menurut Zeithaml dan L. Berry (2009:104) adalah penilaian pelanggan atas produk ataupun jasa dalam hal menilai apakah produk atau jasa tersebut telah memenuhi kebutuhan dan ekspektasi pelanggan. Kepuasan pelanggan dapat disimpulkan sebagai kunci untuk memberikan kepuasan pada pelanggan adalah berusaha mengetahui terlebih dahulu apa yang dibutuhkan dan diinginkan oleh pelanggan (Kotler, Philip T., Keller, Kevin Lane, 2014, p. 164). Jika performance gagal memenuhi ekspektasi, maka pelanggan menjadi tidak puas atau sebaliknya Jika sesuai dengan ekspektasi, maka pelanggan menjadi puas atau jika melebihi maka akan menjadi sangat puas atas penilaian pelanggan.

Hipotesis dikembangkan untuk menjawab tujuan penelitian dan sangat penting diuji untuk menjawab hasilnya secara empiris (Supranto \& Limakrisna, 2019, p. 4). Framework hendaknya disusun untuk mempermudah kerangka berpikir yang diturunkan menjadi suatu model. Menurut Sari (2018), model dapat diartikan sebagai karakteristik utama atau turunan atas pengambilan keputusan yang sistematis untuk menggambarkan fenomena atas suatu objek (Zailani, Husain, \& Budiyantara, 2020). Objek penelitian ini adalah konsumen ojek online yang pernah menggunakan produk Go-Jek. Dengan demikian, model penelitian ini ditetapkan sebagai berikut:

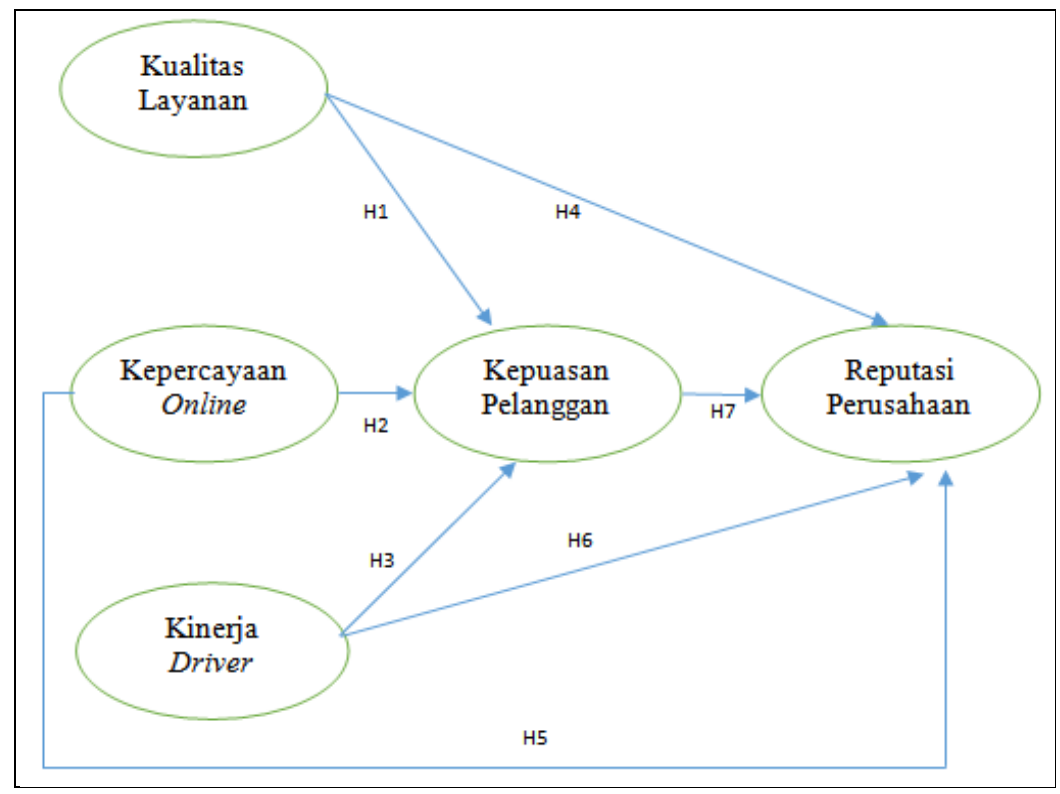

Sumber: Peneliti, 2020

Gambar 2. Model Penelitian

Model penelitian di atas akan dituangkan ke dalam hipotesis alternatif untuk memberikan pernyataan atas temuan-temuan hasil penelitian terdahulu. Hasil penelitian yang membuktikan bahwa kualitas layanan berpengaruh positif terhadap kepuasan yang 
menggunakan atribut kualitas layanan (SERVQUAL) (Husda, 2017) dan bukti kualitas pelayanan yang juga berpengaruh atas kepuasan (Khoi \& Cuong, 2019). Kepercayaan memberikan keyakinan bahwa pihak lain itu dapat diandalkan dan tidak manipulatif dan berkomitmen pada janjinya yang didasarkan pada integritas, kebaikan, dan kompetensi. Hasil penelitian yang membuktikan bahwa kepercayaan berpengaruh positif terhadap kepuasan (Husda, 2017) dan temuan kepercayaan yang juga berpengaruh atas kepuasan (Khoi \& Cuong, 2019). Kinerja karyawan dalam memberikan pelayanan yang berkualitas merupakan salah satu strategi untuk dapat memberikan kepuasan pada pelanggan karena kepuasan pelanggan merupakan langkah awal untuk memperoleh kesetiaan dari konsumen. Adanya konsumen-konsumen yang setia akan memperkuat posisi perusahaan dalam persaingan yang semakin kuat. Hasil penelitian yang membuktikan bahwa secara keseluruhan pelanggan merasakan puas dan loyal terhadap kinerja karyawan, artinya pelanggan mendapat kepuasan sehingga menimbulkan sikap loyal terhadap kinerja karyawan (Nursiti \& Fedrick, 2018) dan temuan kinerja karyawan yang juga berpengaruh pada kepuasan pelanggan (Sasongko \& Putri, 2017). Hasil telaah penelitian terdahulu melatarbelakangi penelitian ini untuk kembali merumuskan hipotesis alternatif berikut ini:

$\mathbf{H}_{1}$ : Kualitas layanan berpengaruh terhadap kepuasan pelanggan

$\mathbf{H}_{2}$ : Kepercayaan online berpengaruh terhadap kepuasan pelanggan

$\mathbf{H}_{3}$ : Kinerja driver berpengaruh terhadap kepuasan pelanggan

Manajemen harus memahami keseluruhan layanan yang ditawarkan dari sudut pandang pelanggan. Kualitas layanan yang dibentuk dari sudut pandang pelanggan dapat memberikan nilai lebih terhadap produk yang ditawarkan. Hasil penelitian yang membuktikan bahwa kualitas akan memberikan dorongan kepada pelanggan untuk menjalin ikatan hubungan yang kuat atau semakin baik kualitas pelayanan maka akan semakin baik reputasi perusahaan (Achmadi, 2008), dan juga temuan kualitas layanan yang berpengaruh terhadap reputasi dealer (Widyastuti, Prasetyo, \& Gustari, 2017). Reputasi secara luas diakui sebagai salah satu kriteria utama yang digunakan untuk menilai kepercayaan calon wali amanat dan membuktikan hubungan yang positif antara kepercayaan online dengan persepsi reputasi perusahaan (Broutsou \& Fitsilis, 2012), dan juga temuan kepercayaan konsumen yang berpengaruh terhadap reputasi dealer (Widyastuti, Prasetyo, \& Gustari, 2017). Adanya konsumen-konsumen yang setia akan memperkuat posisi perusahaan dalam persaingan yang semakin kuat untuk meningkatkan kinerjanya. Kinerja karyawan merupakan suatu hal yang perlu diperhatikan dimana bukti empiris menyatakan bahwa kinerja karyawan berpengaruh positif terhadap reputasi perusahaan (Wahyuni T. , 2015). Reputasi menjadi tujuan sekaligus merupakan prestasi yang hendak dicapai bagi dunia public relations, hal ini menyatakan bahwa peran customer satisfaction secara signifikan berpengaruh terhadap reputasi dalam arti semakin pelanggan puas akan semakin meningkatkan reputasi (Widyastuti, Prasetyo, \& Gustari, 2017). Hasil telaah penelitian terdahulu melatarbelakangi penelitian ini untuk merumuskan hipotesis alternatif berikut ini:

$\mathbf{H}_{4}$ : Kualitas layanan berpengaruh terhadap reputasi perusahaan

$\mathbf{H}_{5}$ : Kepercayaan online berpengaruh terhadap reputasi perusahaan

$\mathbf{H}_{6}$ : Kinerja driver berpengaruh terhadap reputasi perusahaan 
$\mathrm{H}_{7}$ : Kepuasan pelanggan berpengaruh terhadap reputasi perusahaan

\section{Metode Penelitian}

Jenis penelitian ini merupakan eksplanatori (explanatory research), yang memiliki tujuan atas untuk uji antar variabel yang dirumuskan hipotesisnya dalam rangka membuktikan kebenarannya. Metode penelitian kuantitatif dan menggunakanpendekatan deskriptif dengan tujuan untuk mendeskripsikan objek penelitian ataupun hasil penelitian yang dirangkum ke dalam metode penelitian campuran (mix-methods) (Sugiyono, 2017).

Pengukuran variabel Kualitas Layanan menggunakan 5 (lima) dimensi dengan 10 (sepuluh) indikator yaitu dimensi tangibles, reliability, responsiveness, assurance dan empathy (Tjiptono, 2019). Pengukuran variabel Kepercayaan Online menggunakan 5 (lima) dimensi dengan 10 (sepuluh) indikator yaitu dimensi perceived usefulness, perceived ease of use, perceived enjoyment of technology, perceived privacy and security, dan company competency. Dimensi ini digunakan oleh penelitian dalam konsep model penerimaan teknologi, dan dimensi privacy and security adalah akses yang memungkinkan pengguna untuk mendelegasikan beberapa pengendalian serta privasi adalah perhatian langsung pada tingkat pengamanan transaksi melalui internet dan pengamanan informasi pelanggan (Husain \& Budiyantara, 2020). Pengukuran variabel Kinerja Driver menggunakan 4 (empat) dimensi dengan 8 (delapan) indikator yaitu dimensi efektifitas dan efisiensi, tanggungjawab terhadap pekerjaan, disiplin, dan inisiatif penyelesaian masalah (Sasongko \& Putri, 2017). Pengukuran variabel Kepuasan Pelanggan menggunakan 3 (tiga) dimensi dengan 7 (tujuh) indikator yaitu dimensi attributes related to product, attributes related to service dan attributes related to purchase. Pengukuran variabel Reputasi Perusahaan menggunakan 4 (empat) dimensi dengan 7 (tujuh) indikator yaitu dimensi kredibilitas, terpercaya, keterandalan, dan tanggungjawab sosial.

Populasi penelitian adalah seluruh pengguna Ojek Online Go-Jek di wilayah Jakarta, Depok, Bogor dan Bekasi pada tahun 2020 yang jumlahnya tidak diketahui secara pasti. Oleh karena itu diperlukan teknik penetapan sampel untuk menyeleksi jumlah responden yang diteliti. Hair et al. (2014) memberikan rekomendasi jumlah sampel minimal yang dibutuhkan yaitu setidaknya 5 (lima) dikalikan jumlah variabel indikator sehingga sampel akhir yang ditetapkan pada penelitian ini yaitu 199 responden telah memenuhi persyaratan di atas. Kuesioner sebagai alat pengumpul data yang diukur menggunakan skala Ordinal yang berupa pemeringkatan dan pengkategorian yang berfungsi untuk mengukur sikap, pendapat, dan persepsi seseorang atau sekelompok orang tentang fenomena sosial dengan rentang skala yang diberikan antara skor 1 hingga skor 5 untuk menegetahui derajat responden (Sugiyono, 2017, p. 95)

Teknik analisis data menggunakan model persamaan struktural (structural equation modeling) atau disingkat dengan SEM. Alat bantu pengolahan data penelitian ini menggunakan aplikasi atau software SmartPLS. Setelah itu, dilakukan evaluasi terhadap model SEM untuk mendapatkan dan mengevaluasi kecocokan yang diajukan dan selanjutnya akan menguraikan hasil pembahasan serta kesimpulan berdasarkan hasil analisis dimaksud. 


\section{Hasil dan Pembahasan}

Hasil penelitian ini diawali dengan menyajikan profil 210 responden pengguna Ojek Online Go-Jek di wilayah Jakarta, Depok, Bogor dan Bekasi berdasarkan kategori jenis kelamin, umur, pengelompokkan pegawai dan pengusaha serta pekerjaan saat ini.

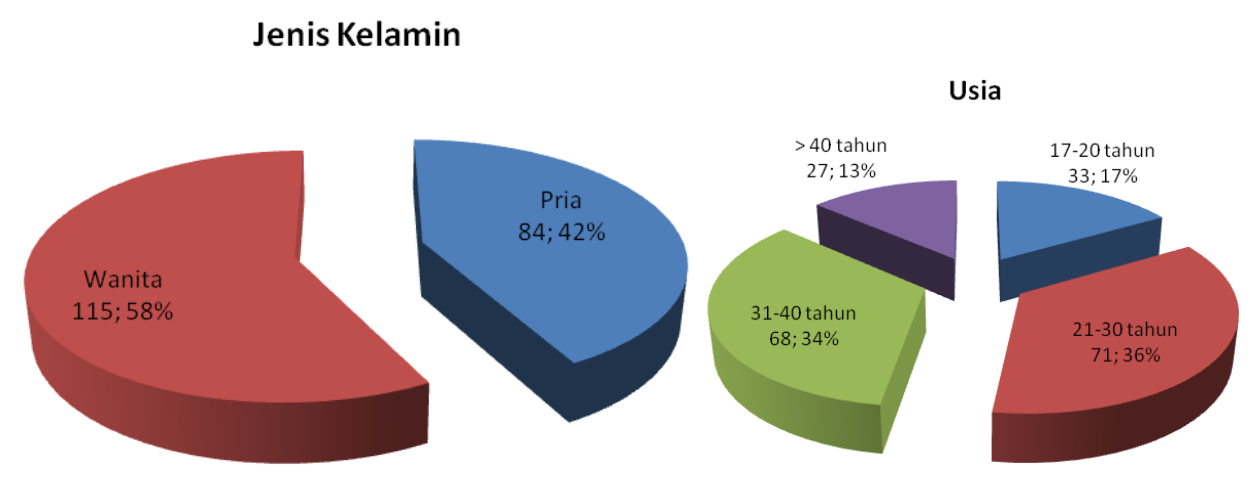

Gambar 3. Diagram Pie berdasarkan Jenis Kelamin dan Usia Sumber: Data Primer Diolah, 2020

Gambar 3 di atas menyajikan kriteria responden diantaranya 84 responden adalah Pria sebesar 42 persen dan sisanya berjumlah 115 responden adalah Wanita sebesar 58 persen. Sedangkan kriteria berdasarkan usia, 17 persen responden berusia antara 17 hingga 20 tahun, 36 persen responden berusia antara 21 hingga 30 tahun, 34 persen responden berusia 31 hingga 40 tahun dan 13 persen responden orang yang berusia lebih dari 40 tahun.
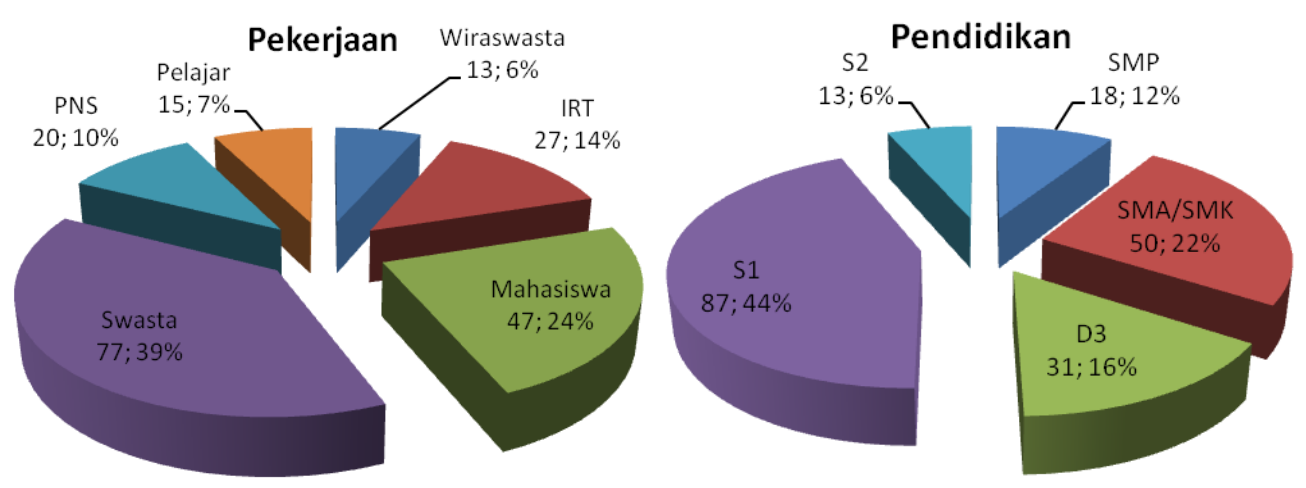

Gambar 4. Diagram Pie berdasarkan Pekerjaan dan Latar Belakang Pendidikan Terakhir Sumber: Data Primer Diolah, 2020

Gambar 4 di atas menyajikan kriteria responden diantaranya mayoritas adalah 243 responden adalah seorang mahasiswa dan bekerja di perusahaan swasta masing-masing sebesar 24 persen dan 39 persen, sisanya sebesar 37 persen memiliki pekerjaan sebagai PNS, Pelajar, Wiraswasta dan Ibu Rumah Tangga. Sementara data latarbelakang pendidikan dari keseluruhan responden mayoritas memiliki latar belakang pendidikan S1 sebesar 44 persen, 38 persen diantaranya adalah SMA/SMK dan D3, 13,6 persen adalah pendidikan S2 dan sisanya 12 persen adalah pendidikan SMP.

Pengujian Model Pengukuran (Outer Model) memberikan output bahwa variabel laten Kualitas Layanan menggunakan 10 (sepuluh) indikator yang memiliki r-hitung yang berkisar antara 0,549 hingga tertinggi 0,766, artinya dinyatakan sah atau valid dalam 
mengukur variabel Kualitas Layanan. Variabel laten Kepercayaan Online menggunakan 10 (sepuluh) indikator yang memiliki r-hitung yang berkisar antara 0,254 hingga tertinggi 0,696, artinya dinyatakan sah atau valid dalam mengukur variabel Kepercayaan Online. Variabel laten Kepercayaan Online menggunakan 10 (sepuluh) indikator yang memiliki r-hitung yang berkisar antara 0,254 hingga tertinggi 0,696, artinya dinyatakan sah atau valid dalam mengukur variabel Kepercayaan Online. Variabel laten Kinerja Driver menggunakan 8 (delapan) indikator yang memiliki r-hitung yang berkisar antara 0,548 hingga tertinggi 0,724, artinya dinyatakan sah atau valid dalam mengukur variabel Kinerja Driver. Variabel laten Kepuasan Pelanggan menggunakan 7 (tujuh) indikator yang memiliki r-hitung yang berkisar antara 0,406 hingga tertinggi 0,683, artinya dinyatakan sah atau valid dalam mengukur variabel Kepuasan Pelanggan. Variabel laten Reputasi Perusahaan juga menggunakan 7 (tujuh) indikator yang memiliki r-hitung yang berkisar antara 0,593 hingga tertinggi 0,785, artinya dinyatakan sah atau valid dalam mengukur variabel Reputasi Perusahaan.

Pengujian Model Struktural (Inner Model) yang digunakan untuk menentukan spesifikasi hubungan antara variabel laten dengan variabel laten lainnya dilakukan pengujian meliputi menentukan nilai koefisien jalur, nilai $\mathrm{R}^{2}$ dan menentukan nilai $\mathrm{t}$ (Sani, Wiliani, \& Husain, 2019). Nilai-nilai di atas didapatkan dengan prosedur bootstrapping pada SEM yang dirangkum pada output hasil uji hipotesis berikut ini:

Tabel 3. Rangkuman Hasil Uji Hipotesis (Direct Effect)

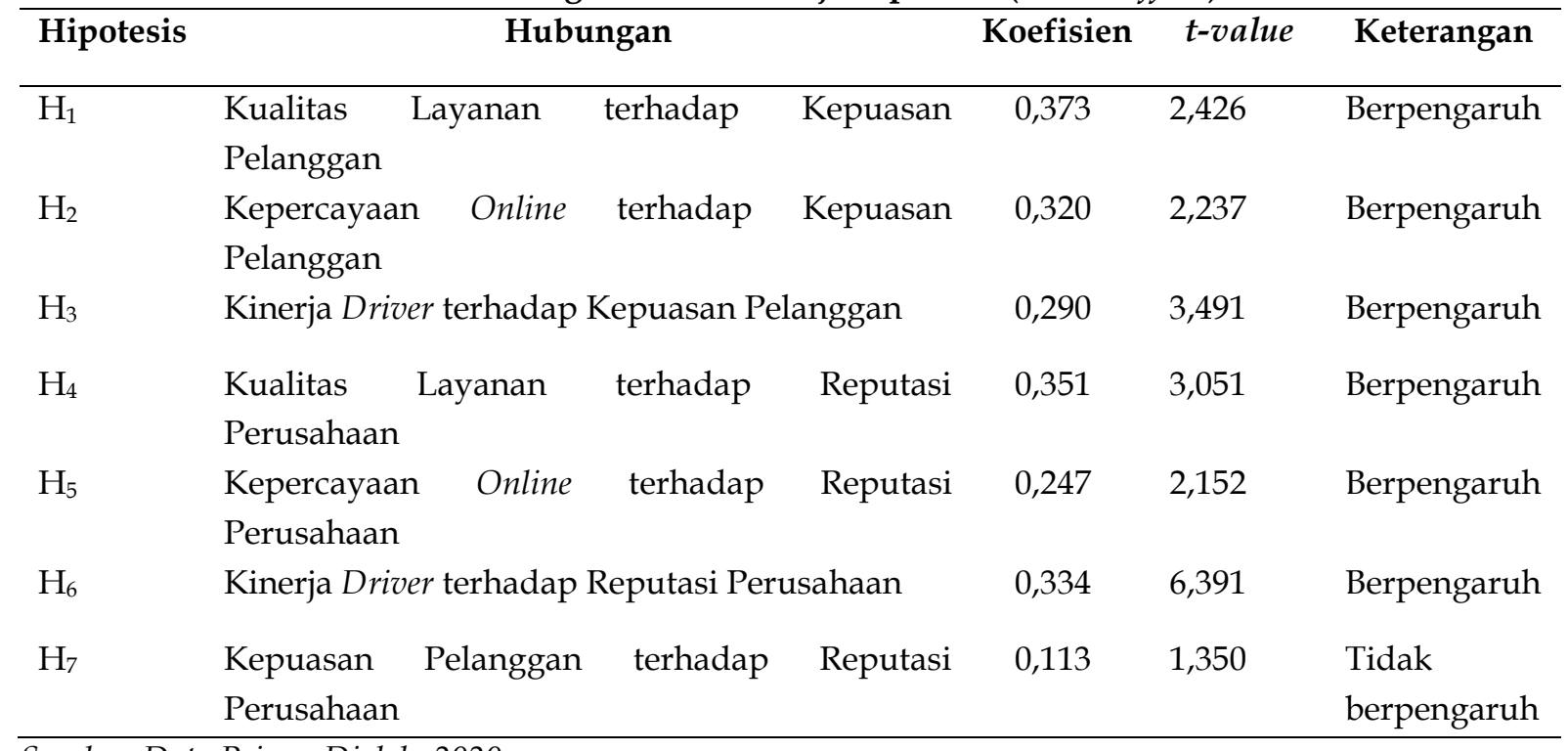

Sumber: Data Primer Diolah, 2020

Rangkuman penelitian berdasarkan hasil uji hipotesis pada Tabel 3 dari masing-masing pengaruh yang diuji. Kualitas Layanan berpengaruh terhadap Kepuasan Pelanggan Go-Jek, yang menghasilkan koefisien sebesar 0,373 yang artinya setiap peningkatan satu satuan kualitas layanan maka berpengaruh secara signifikan atas peningkatan kepuasan pelanggan sebesar 37,3 persen dengan t-value senilai 2,426. Temuan ini sesuai dengan bukti empiris yang menunjukkan atas bahwa kualitas berpengaruh positif terhadap kepuasan (Husda, 2017; Khoi \& Cuong, 2019). Kualitas layanan adalah hasil penilaian pelanggan atas seberapa jauh perbedaan antara harapan dan kenyataan yang dirasakan dari suatu layanan yang mereka terima dari penyedia layanan (Go-Jek), baik penilaian itu secara sebagian maupun 
menyeluruh. Kepercayaan Online berpengaruh terhadap Kepuasan Pelanggan Go-Jek, yang menghasilkan koefisien sebesar 0,320 yang artinya setiap peningkatan satu satuan kepercayaan online maka berpengaruh secara signifikan atas peningkatan kepuasan pelanggan sebesar 32 persen dengan t-value senilai 2,237. Temuan ini sesuai dengan bukti empiris yang menunjukkan atas bahwa kepercayaan juga berpengaruh positif terhadap kepuasan (Husda, 2017; Khoi \& Cuong, 2019). Kinerja Driver berpengaruh terhadap Kepuasan Pelanggan Go-Jek, yang menghasilkan koefisien sebesar 0,290 yang artinya setiap peningkatan satu satuan kinerja driver maka berpengaruh secara signifikan atas peningkatan kepuasan pelanggan sebesar 29 persen dengan t-value senilai 3,491. Temuan ini sesuai dengan bukti empiris yang menunjukkan atas bahwa kinerja karyawan yang berpengaruh positif terhadap kepuasan pelanggan (Sasongko \& Putri, 2017). Kinerja driver ini merujuk pada apa yang dilakukan dan tidak dilakukan oleh karyawan (driver).

Kualitas Layanan berpengaruh terhadap Reputasi Perusahaan, yang menghasilkan koefisien sebesar 0,351 yang artinya setiap peningkatan satu satuan kualitas layanan maka berpengaruh secara signifikan atas peningkatan reputasi perusahaan sebesar 35,1 persen dengan t-value senilai 3,051. Temuan ini sesuai dengan bukti empiris yang menunjukkan pengaruh atas kualitas pelayanan terhadap reputasi perusahaan dan dealer (Achmadi, 2008; Widyastuti, Prasetyo, \& Gustari, 2017). Reputasi perusahaan akan meningkat seiring dengan semakin baiknya kualitas layanan yang diberikan pihak Go-Jek. Kepercayaan Online berpengaruh terhadap Reputasi Perusahaan, yang menghasilkan koefisien sebesar 0,247 yang artinya setiap peningkatan satu satuan kepercayaan online maka berpengaruh secara signifikan atas peningkatan reputasi perusahaan sebesar 24,7 persen dengan t-value senilai 2,152. Temuan ini sesuai dengan bukti empiris yang menunjukkan pengaruh atas kepercayaan online dengan persepsi reputasi perusahaan (Broutsou \& Fitsilis, 2012), dan juga reputasi dealer (Widyastuti, Prasetyo, \& Gustari, 2017). Kepercayaan konsumen dapat meningkat secara signifikan bila suatu perusahaan dipersepsikan memiliki reputasi yang baik dan dirasakan sehingga orang percaya pada kejujuran dan kepedulian perusahaan terhadap pelanggannya. Kinerja Driver berpengaruh terhadap Reputasi Perusahaan, yang menghasilkan koefisien sebesar 0,334 yang artinya setiap peningkatan satu satuan kinerja driver maka berpengaruh secara signifikan atas peningkatan reputasi perusahaan sebesar 33,4 persen dengan t-value senilai 6,391. Temuan ini sesuai dengan bukti empiris yang menunjukkan pengaruh atas kinerja karyawan terhadap reputasi perusahaan (Wahyuni T. , 2015). Perusahaan bereputasi baik artinya perusahaan memiliki sumberdaya manusia yang berharga, serta mempunyai sumber keunggulan daya saing untuk mendapatkan profitabilitas yang diinginkan. Kepuasan Pelanggan tidak berpengaruh terhadap Reputasi Perusahaan, yang menghasilkan koefisien sebesar 0,113 yang artinya setiap peningkatan satu satuan kepuasan pelanggan maka berpengaruh secara tidak signifikan atas peningkatan reputasi perusahaan hanya sebesar 11,3 persen dengan t-value senilai 1,350. Temuan ini tidak sesuai dengan bukti empiris yang menunjukkan pengaruh signifikan atas customer satisfaction terhadap reputasi (Widyastuti, Prasetyo, \& Gustari, 2017). Namun masih adanya sejumlah keluhan pelanggan seperti adanya driver Go-Jek yang tidak datang kepada pelanggan dengan cepat, driver yang kurang rapi dan bersih dalam 
penampilannya, aplikasi Go-Jek terkadang mengalami error. Ketidakpuasan atas kepercayaan online diantaranya adanya kekhawatiran keamanan dalam melakukan pembayaran online dan perusahaan kurang menjalin interaksi kepada pelanggan. Keluhan pelanggan atas kinerja driver yang terjadi akan mengurangi kepuasan pelanggan dalam memanfaatkan layanan Go-Jek sehingga kepuasan pelanggan yang terjadi tidak berdampak signifikan dalam meningkatkan reputasi perusahaan.

Hasil analisis strategi menggunakan tahapan strategi input stage dengan Competitive Profile Matrix (CPM), matching stage dengan Threats, Opportunities, Weakness, Strengths (TOWS) dan decision stage dengan Quantitative Strategic Planning Matriks (QSPM) maka dapat disimpulkan strategi yang digunakan dari hasil QSPM adalah strategi alternatif pengembangan produk. Go-Jek masih mempertahankan fitur-fitur produk layanan mereka agar dapat bersaing dengan kompetitor lain dan dapat mendominasi pasar transportasi online serta posisi terbaik di pasar transportasi online yang dapat dilihat dari faktor eksternal maupun internal yang menjadi penilaian akan produk dan penilaian Go-jek di mata pelanggan maupun perusahaan dalam meningkatkan reputasi perusahaan. Hal tersebut dapat dilihat dari partnership dan merchant Go-jek yang terus bertambah dalam pemanfaatan fitur Go-jek yang bertujuan memenuhi kebutuhan konsumen bertransaksi.

\section{Penutup dan Saran}

Berdasarkan penelitian di atas tentang pengaruh dan analisis strategi kualitas pelayanan untuk meningkatkan reputasi perusahaan yang melibatkan sebanyak 199 responden pelanggan Go-Jek di Jakarta, Depok, Bogor dan Bekas maka simpulan penelitian ini adalah:

a) Kualitas Layanan, Kepercayaan Online, dan Kinerja Driver masing-masing berpengaruh terhadap Kepuasan Pelanggan Go-Jek. Temuan penelitian ini menunjukkan bahwa pelayanan yang diberikan Go-Jek melalui aplikasinya memberikan keemudahan dengan sebuah kualitas layanan yang dapat dikatakan sesuai dengan apa yang diinginkan, dibayangkan dan diharapkan pelanggan sehingga berdampak baik pada rasa kepuasan pelanggan. Kepercayaan pelanggan dalam transaksi online menggunakan aplikasi Go-Jek, maka hal tersebut berdampak terhadap semakin meningkatnya kepuasan pelanggan dalam menggunakan jasa Go-Jek. Kinerja driver Go-Jek yang terus memberikan yang terbaik dalam pelayanan kepada pelanggan, sehingga pelanggan merasa puas atas hasil kinerja driver.

b) Kualitas Layanan, Kepercayaan Online, dan Kinerja Driver masing-masing berpengaruh terhadap Reputasi Perusahaan. Temuan penelitian ini menunjukkan bahwa layanan yang diberikan sesuai harapan yang diinginkan pelanggan sehingga menciptakan pandangan positif terhadap perusahaan Go-Jek. Pelanggan yang merasa terus percaya akan penggunaan aplikasi Go-Jek dapat menciptakan pandangan baik dan meningkatkan reputasi perusahaan. Kinerja driver yang baik akan menciptakan pandangan yang baik di mata masayarakat dimana pelanggan akan merasa kinerja driver bagus jika sesuai apa yang dibutuhkan oleh pelanggan yang akan menciptakan reputasi perusahaan semakin baik. Akan tetapi, Kepuasan Pelanggan tidak berpengaruh terhadap Reputasi Perusahaan, hal ini disebabkan oleh adanya 
sejumlah harapan pelanggan yang tidak terpenuhi menyebabkan berkurangnya kepuasan yang dirasakan pelanggan sehingga hal tersebut tidak mampu meningkatkan reputasi perusahaan. Dan demikian pelanggan akan merasa butuh tanpa adanya harapan untuk merasa puasan dalam menggunakan Go-Jek agar menciptakan reputasi Go-Jek.

c) Strategi yang digunakan pada kualitas layanan dalam meningkatkan reputasi perusahaan dilakukan dengan input stage (CPM), matching stage (TOWS) dan decision stage (QSPM) yaitu strategi alternatif pengembangan produk. Go-Jek masih mempertahankan fitur-fitur produk layanan mereka agar dapat bersaing dengan kompetitor lain dan dapat mendominasi pasar transportasi online serta posisi terbaik di pasar transportasi online yang dapat dilihat dari faktor eksternal maupun internal yang menjadi penilaian akan produk dan penilaian Go-Jek di mata pelanggan maupun perusahaan dalam meningkatkan reputasi perusahaan. Hal tersebut dapat dilihat dari partnership dan merchant Go-Jek yang terus bertambah dalam pemanfaatan fitur Go-Jek yang bertujuan memenuhi kebutuhan konsumen bertransaksi.

\section{Referensi}

Achmadi, A. (2008). Analisis Variabel-variabel yang Mempengaruhi Reputasi Perusahaan untuk Membangun Kepercayaan dan Minat Beli Konsumen. Value Added: Majalah Ekonomi dan Bisnis, 5(1).

Anindhita, W., Arisanty, M., \& Rahmawati, D. (2016). Analisis Penerapan Teknologi Komunikasi Tepat Guna Pada Bisnis Transportasi Ojek Online (Studi pada Bisnis Gojek dan Grab Bike dalam Penggunaan Teknologi Komuniasi Tepat Guna untuk Mengembangkan Bisnis Transportasi). In Prosiding Seminar Nasional INDOCOMPAC.

Bakrie, M., Sujanto, B., \& Rugaiyah, R. (2019). The Influence of Service Quality, Institutional Reputation, Students' Satisfaction on Students' Loyalty in Higher Education Institution. International Journal for Educational and Vocational Studies, 1(5), 379-391.

Bangun, W. (2012). Manajemen Sumber Daya Manusia. Jakarta: Erlangga.

Broutsou, A., \& Fitsilis, P. (2012). Online trust: the influence of perceived company's reputation on consumers' trust and the effects of trust on intention for online transactions. Journal of Service Science and Management, 5(4), 365-372.

Diza, F., Moniharapon, S., \& Imelda, W. J. (2016). Pengaruh kualitas pelayanan, kualitas produk dan kepercayaan terhadap kepuasan konsumen (studi pada pt. fifgroup cabang manado). Jurnal EMBA: Jurnal Riset Ekonomi, Manajemen, Bisnis dan Akuntansi, 4(1), 109-119.

Erlangga, D. (2014). Pengaruh Kualitas Pelayanan Terhadap Brand Image (Studi pada Hotel Nusantara di Bandar Lampung). Ilmu Administrasi Bisnis. Jakarta: Universitas Telkom.

Hair, J. F., Black, W. C., Babin, B. J., \& Anderson, R. E. (2014). Multivariate Data Analysis (7th, Revised Ed.). London: Pearson Education Limited. 
Husain, T., \& Budiyantara, A. (2020). Analysis of Control Security and Privacy Based on eLearning Users. SAR Journal, 3(2), 51-58.

Husain, T., Sani, A., Ardhiansyah, M., \& Wiliani, N. (2020). Online Shop as an interactive media information society based on search engine optimization (SEO). International Journal of Computer Trends and Technology (IJCTT), 68(3), 53-57.

Husda, N. E. (2017, December). Customer Value And Customer Satisfaction As Mediation Of Mis And Service Quality To Brand Trust And Reputation Of Private Universities In Kepulauan Riau Province. In International Conference on Information Technology and Business (ICITB) 3 (pp. 34-39). Institut Informatika dan Bisnis (IIB) Darmajaya, Lampung.

Cuong, D. T., \& Khoi, B. H. (2019). The Relationship between Service Quality, Satisfaction, Trust and Customer Loyalty A Study of Convenience Stores in Vietnam. Journal of Advanced Research in Dynamic and Control Systems, 11, 327-333.

Kotler, K. K. P., \& Manceau, D. (2012). Marketing management 14e. PEARSON FRANCE.

Kurnianti, A. W. (2017). Komunikasi Pemasaran Transportasi Online NGuberJEK. Jurnal Komunikasi dan Kajian Media, 1(1), 69-84.

Lupiyoadi, R. (2013). Manajemen Pemasaran Jasa: Berbasis Kompetensi (3rd Ed.). Jakarta: Salemba Empat.

Mangkunegara, A. A. (2017). Manajemen Sumber Daya Manusia Perusahaan. Bandung: PT. Remaja Rosdakarya.

Nursiti, D. (2019). Pengaruh Kinerja Karyawan Terhadap Kepuasan dan Loyalitas Pelanggan Chatime. Jurnal Psychomutiara, 2(1), 46-56.

Pujoraharjo, P., ZUNAIDAH, Z., \& DIAH, Y. M. (2015). Pengaruh Kompetensi dan Desain Kerja terhadap Kinerja Karyawan (Studi Kasus di Departemen Gigi dan Mulut Rsup Dr. Mohammad Hoesin Palembang). Jurnal Manajemen Dan Bisnis Sriwijaya, 13(4), 507524.

Quintania, M., Faturachman, D., Husain, T., Pasupati, B., \& Taufik, A. (2021, March). Utilization of GPS Technology in The Maritime Sector on Motor Sailing Yachts. In IOP Conference Series: Earth and Environmental Science (Vol. 698, No. 1, p. 012039). IOP Publishing.

Sani, A., Rahman, T. K. A., Subiyakto, A., \& Wiliani, N. (2019). Combining Statistical and Interpretative Analyses for Testing Readiness and IT Adoption Questionnaire. In SEWORD FRESSH 2019: Proceedings of the 1st Seminar and Workshop on Research Design, for Education, Social Science, Arts, and Humanities, SEWORD FRESSH 2019, April 27 2019, Surakarta, Central Java, Indonesia (p. 90). European Alliance for Innovation.

Sani, A., Khristiana, Y., Zailani, A. U., \& Husain, T. (2020, October). E-Business Adoption Models in Organizational Contexts on The TAM Extended Model: A Preliminary Assessment. In 2020 8th International Conference on Cyber and IT Service Management (CITSM) (pp. 1-5). IEEE. 
Sani, A., Wiliani, N., \& Husain, T. (2019). Spreadsheet Usability Testing in Nielsen's Model among Users of ITSMEs to Improve Company Performance. European Journal of Scientific Exploration, 2(6), 1-9.

Sasongko, N., \& Putri, E. (2017). Pengaruh Kualitas Pelayanan Dan Kinerja Karyawan Terhadap Kepuasan Pelanggan (Study Pada Universitas Muhammadiyah Surakarta). Seminar Nasional dan The $4^{\text {th }}$ Call For Syariah Paper (SANCALL) 2017 (pp. 226-233). Surakarta: Muhammadiyah University Press.

Sudaryana, Y. (2020). Effect Of Compensation And Carerr Development To The Employee Performance (Study At PT. Benesse Indonesia). Journal of Management Review, 4(2), 491500.

Sugiyarto, S., Dewi, D. P., \& Junaedi, E. (2020). Pengaruh Moda Transportasi Berbasis Aplikasi Terhadap Pilihan Masyarakat Dalam Menentukan Moda Transportasi dan Dampaknya Terhadap Pendapatan Driver Ojek Online. Derivatif: Jurnal Manajemen, 14(2).

Sugiyono. (2017). Metode Penelitian Evaluasi: Pendekatan Kuantitatif, Kualitatif, dan Kombinasi. Bandung: CV. Alfabeta.

Supranto, J., \& Limakrisna, N. (2019). Petunjuk Praktis Penelitian Ilmiah untuk Menyusun Skripsi, Tesis dan Disertasi (5 $5^{\text {th }}$ Ed.). Bogor: Penerbit Mitra Wacana Media.

Tjiptono, F. (2019). Pemasaran Jasa: Prinsip, Penerapan, dan Penelitian (Cetakan 1) (II Ed.). Yogyakarta: Penerbit Andi.

Wahyuni, R. S., \& Setyawati, H. A. (2020). Pengaruh Sales Promotion, Hedonic Shopping Motivation dan Shopping Lifestyle Terhadap Impulse Buying Pada E-Commerce Shopee. Jurnal Ilmiah Mahasiswa Manajemen, Bisnis Dan Akuntansi (JIMMBA), 2(2), 144154.

Wahyuni, T. (2015). Analisis Faktor-Faktor Yang Mempengaruhi Reputasi Perusahaan Studi Kasus Pada PT. Satwa Borneo Jaya Breeding Farm. Jurnal Manajemen Update, 4(4).

Widyastuti, S., Prasetyo, H., \& Gustari, I. (2017). An Investigating On The Purchase Intention: Developing Dealers Reputation Through Customer Trust And Service Quality. European Journal of Social Sciences, 54(3), 316-331.

Windasari, W., \& Zakiyah, T. (2019). Analisis Game Theory pada Strategi Bersaing Grab dan Go-Jek di Kabupaten Kebumen. Fokus Bisnis: Media Pengkajian Manajemen dan Akuntansi, 18(2), 22-28.

Wulandari, A., \& Rasipan, R. (2018). Peran Reputasi dalam Membangun Kepercayaan Konsumen. Jurnal Manajemen Kewirausahaan, 14(2), 121-132.

Zaelani, A. U., Husain, T., \& Budiyantara, A. (2020). Analisis Simulasi Sistem Penunjang Keputusan: Model Matematis Dengan Pendekatan Goodness-of Fit Berbasis Structural Equation Model. SMARTICS Journal, 6(1), 10-16.

Zeithaml, V. A., Bitner, M. J., \& Gremler, D. D. (2009). Services Marketing: Integrating Customer Focus Across the Firm (5 $5^{\text {th }}$ Ed.). Boston: McGraw Hill. 